\title{
A Beautiful, Sad Tale about Nonexistent Socialism in Hungary: The Story of Gyuri Cséplö
}

\section{György Majtényi}

gyorgymajtenyi@hotmail.com

ORCID: https://orcid.org/0000-0002-4549-2198

György Majtényi is a social historian and professor at Károly Eszterházy University. Between 2000 and 2011, he was department head of the National Archives of Hungary. He received a PhD in 2004 from Eötvös Loránd University with a thesis on social mobility in post-1945 Hungary and his habilitation in 2010. His recent research interests include Roma social history, twentieth century history in East Central Europe, intellectual history, and historiography.

\section{Critical}

Romani Studies 


\section{Abstract}

In the 1970s, director Pál Schiffer and his colleagues filmed the life story of Cséplö Gyuri (1978), a documentary feature about the prospect of a Gypsy protagonist breaking free from a slum in socialist Hungary. The original footage from the production is held in the Vera and Donald Blinken Open Society Archives in Budapest. The footage brings to light how the Gypsy/Romani protagonist of the film was cast, how he was brought from a Gypsy settlement in Németfalu to Budapest, how the film was screened, how audiences reacted, and what the filmmakers debated with local communities. The tragic early death of Gyuri Cséplö raised the question among the filmmakers how it would be possible to break free from poverty and from Gypsy settlements. In a social critique, the filmmakers presented a parallel world outside that of modern socialist Hungary. The theory of multiple modernities and studies written as a result - suggest that modernization is not a singular phenomenon; that it affected various social and ethnic groups and actors in divergent ways. This microhistory investigates what differences can be revealed between the perspectives of minority and majority communities in socialist Hungary.

\section{Keywords}

- Central Europe

- Ethnicity

- Microhistory

- Modernity

- Modernization

- Pál Schiffer

- Poverty

- Roma social history

- Situational documentary

- Socialism 


\section{Introduction}

In 1978, screenings and debates were organized across socialist Hungary for the feature documentary Cséplő Gyuri directed by Pál Schiffer. The groundbreaking film focused on a young Gypsy/Romani protagonist and his journey from a sleepy rural settlement to the busy urban capital (Szekfü 1980, 2008). ${ }^{[1]}$ During a debate in the village of Zalakomár, participants remarked that at first they were ashamed by a film showing the same poverty they knew and lived. One woman commented:

[...] I liked the film because it was very realistic and it illustrated reality, and I completely agree with Géza (another person commenting in Zalakomár) when he said that he was ashamed of the film - poverty is not a shame, it's only unpleasant. ${ }^{[2]}$

Once screened, Cséplö Gyuri raised important questions about the existence of poverty, the possibility of social mobility, equal opportunities, and the realization of justice, which even today are difficult to answer unambiguously. According to one system of views on modernity, social and economic development resulted in the birth and/or creation of modernity and social welfare. Looking back, it may appear that today's Eastern and Central European societies were born from transformations in the twentieth century (Giddens 1990; Wolff 1997), and the period of (soviet or state) socialism was essentially one chapter in this linear development. From the power discourses ${ }^{[3]}$ of the period it follows that socialism in Hungary improved the quality of life, increased social justice, and established relative welfare for all. The socialist transformation also can be interpreted as modernization via the above experiment. However, in the spirit of theories about "multiple modernities," it remains to be seen whether a uniform assessment of social processes is possible (David-Fox 2006). Accordingly, modernization does not necessarily have to be viewed as a homogeneous phenomenon. It also can be a multifaceted process that takes place in a different way, at a different pace, in different regions of Europe and the other continents, and even within certain countries, societies, and smaller communities (in the spaces of localities) (Eisenstadt 2003).

Some research has been published analyzing the place of Gypsies/Roma in European discourses on modernity and on modern state policies. Modern states regarded Gypsies as "internal outsiders," and official discourses on Gypsies emphasized the differences between modern (majority) society and Gypsy

1 OSA 356-1-4 1. c; OSA 356-1-4 3. c.

2 OSA 356. f. 1-4 1. c. “Cséplő Gyuri debate," Zalakomár (1978).

3 By power discourses I mean those strategic, linguistic, and conceptual efforts of the contemporary power/ruling system which, in the interest of its own legitimacy, were used to create the public sphere of the time and which tried to exclude or eradicate those social actors, phenomena, and experiences that weakened this legitimacy. State institutions not only created unique dependence systems in the societies of the socialist era, but their functioning and the discourses they created made it nearly impossible for those living in poverty to express and present their individual and collective experiences to the public. For more information, see: Lindenberger 2003. 
communities, showing them as traditional or archaic. Gypsies/Roma ${ }^{[4]}$ could not represent their inner viewpoints in public discourse due to their peripherical social status.

It is also important to underline how the ideal of social justice could be realized during the decades of socialism, and whether social processes and modernization can be judged uniformly or there may be multiple points of view. Did a regime labelling itself as socialist really offer everyone the opportunity to break out of poverty and misery? Can the transformations of the period be described uniformly as modernization? What differences can be revealed between the perspective of the minority and majority communities?

\section{Documentaries on the Gypsy Issue}

In the film Cséplö Gyuri the director aimed to paint a general picture of poverty by presenting the social position of Gypsies and the story of one single Gypsy man. Trends in cinema and arts in East and Central Europe have tended to portray Gypsies as representatives of presocialist (premodern) society and as failures of modernization, whose situation shows the contrast between the "old" and the "new world" (DeCuir 2011). Encoded Gypsy difference has its roots in prewar societies where portrayals of Gypsies - by members of majority societies - were connected also to a lack of progress, and mainly static images were associated with them (Kovács 2009). Several artists were inspired by the situation of the Gypsy population in the socialist era in Hungary. Besides the scenes documenting the "Gypsies' upward mobility” in the socialist (modern) world, Sára Sándor’s 1962 short film Cigányok (Gypsies) presented images mainly about poverty, portraying them as "internal outsiders" in socialist Hungary. The snapshots fundamentally demonstrate the differences between the old and new worlds. Pál Schiffer spoke about the film later:

At that time somehow it was the film by Sándor Sára which was a decisive and basic experience, both as a film and a method of filmmaking in the film industry for ten years, and from a cinematic point of view we considered it a little taboo to deal with the Gypsy issue saying that a better film than that cannot be done. ${ }^{[5]}$

On balance, Pál Schiffer's documentaries had their greatest impact in the 1970s and 1980s. Several of Schiffer's films resonated a great deal at the time and dealt with the "Gypsy issue," and more specifically the social question of poverty, which was considered to be the "Gypsy issue" ${ }^{[6]}$ in Hungary. Fekete vonat

\footnotetext{
4 In the historical parts of my analysis I adopt the word "Gypsy," which was commonly used in that era, instead of the word "Roma." While the former term primarily is used today to express minority identity, in the 1960s and 1970s, the latter preferred to indicate a social situation that was not independent of being a minority. This social situation and poverty determined the collective experiences of Gypsy communities in many cases.
}

5 OSA 356. f. 1-4 1. c. “Cséplö Gyuri debate," Csillebérc (31March 1978).

6 In this text, "Gypsy issue" relates to Gypsy policy of the socialist system, its effects, and how these were presented in public discourse. 
(Black train - 1970) depicted the world of work (the atmosphere of a workers' commuter train), Mit csinálnak a cigány gyerekek? (What are Gypsy children doing? - 1972) presented the world of schools, whereas Faluszéli házak (Houses at the edge of the village - 1973) was about the difficulty of breaking free from a Gypsy slum.

Cséplö Gyuri (1978) can be categorized as a situational documentary, i.e., the director described the real life of an ordinary person in the scenes (among the sets of existing socialism). This genre, combining both fictional and documentary elements, already was in existence in contemporary Hungarian filmmaking. Fotográfia (Photography) directed by Pál Zolnay was made at the Hunnia Film Studio in 1972, and István Dárday's Jutalomutazás (The prize trip) was shot at the Budapest Film Studio in 1974 (Pócsik 2013).

"The film is written by life," said Schiffer about the genre later, and as for the film, he said that he had meant to form "a type of hero that has not been seen before": we were looking for "a hero who bears the film in his life" ${ }^{[7]}$ (Pócsik 2013). This genre blazed a trail that allowed filmmakers to create a new filmic Gypsy archetype whose personal example could change prejudices against Gypsies in Hungary.

\section{Gyuri Cséplő: Protagonist}

During preproduction, Schiffer sought to cast a "Gypsy boy" whose personal story made it possible to present the itinerant lifestyle of Hungary's poorest workers traveling from their villages to towns for work. The director chose a 21-year-old living in a Gypsy settlement as his protagonist. In his notes he writes how, after three months of persistent research, he and the sociologist István Kemény found Gyuri Cséplö, the leader of a community living in a segregated settlement near Németfalu, a small village in Zala County. For the film they help him secure a job in the capital, Budapest, find him accommodation at a workers' hostel, facilitate the protagonist's opportunities to learn, and enable everything that allows this ambitious young man to rise from poverty.

Together with two young men from the village, Gyuri starts his journey from home. We watch the young men attempt to overcome various challenges at locations that are strange to them: railways stations, underground stations and hotels. They are looking for work, and they first apply to one of Budapest's largest employers, the Cordatic Rubber factory. Only our hero is offered a job while his illiterate companions will be brushed aside. His companions - Gyuri's brother and his friend - give up and go home. Gyuri, however, stays on, alone in the hustle and bustle of the strange capital.

Pál Schiffer's protagonist visits some locations which the makers thought important to show. For example, Gyuri goes to a terraced housing estate, part of a brick-workers' settlement, which captures the tenacity of prewar poverty in postwar Hungary. In the end, a young Gypsy man recommends Gyuri to a construction firm, and from then on he lives in its modern workers' hostel. He also starts going to

7 OSA 356. f. 1-4 1. c. 
evening classes, and he visits a Gypsy club in Rákospalota (a suburb of Budapest), ${ }^{[8]}$ where he meets Gypsy intellectuals and artists. By the end of the film, he returns home in a taxi, wearing urban clothes and bringing gifts. However, his heart urges him back to the socialist (modern) metropolis, and Gyuri Cséplö tells his brother, "I'm going back." At the end of the film a song can be heard: "Oh my God, my dear God, oh, dear, when will I have a happy life?"[9] (The original script proposes that his brother also take to the road at the end: "Pista, Gyuri's younger brother, also says that he will go with him: - Are you coming? - I'm coming." ${ }^{[10]}$ )

Pál Schiffer's Cséplő Gyuri effectively created - while presenting realistic pictures from the life of an ordinary man - a new Gypsy archetype in Hungarian film, a character who forms his own life path and who can negotiate the social barriers between Gypsy and non-Gypsy communities. The filmmakers attempted to challenge and transform the discourse about the situation of Gypsies in socialist Hungary, and they presented a dynamic picture of these communities instead of stereotypes that have tended to strengthen social distance between minority and majority communities.

\section{Social Historical Context of the Film}

The effects of industrialization, urbanization, and the disintegration of traditional communities also aroused the interest of ethnographers in Hungary in the 1950s (Bakó 1954; Ladvenicza 1955; Gunda 1956; Apor $2009,78)$. In a period of intense industrialization, the archaic lifestyle of some Gypsy communities could be shown as a remnant of a prewar world. Actually, Gypsy communities were quite diverse in this era, and often had deeper connections to local majority communities than to each other. However, in these researches "Gypsies" appear to be the sole messengers of an era before socialism (before socialist modernity), and these descriptions imply that they lived outside the world of socialism (as "internal outsiders").

According to its own propaganda, the socialist system established industry and raised living standards, and it also contributed to the elimination of ethnic and national disparities, e.g., a modernized Hungary. By the 1960s the regime proclaimed the successful assimilation of Gypsy communities. The communist party's political bureau decreed in 1961 that Gypsies “...despite having some ethnographic uniqueness, do not constitute a national minority" and dealt with the "Gypsy issue" as a social policy question for some time to come. The decree also stated that: "Work and settlement have a definitive role in the development of the situation of the Gypsy population." ${ }^{[11]}$ In the spirit of the party decree, the policy of

8 On the history of the Gypsy Club, see György 2019.

9 OSA 356. f. 1-4 1. c. Cséplő Gyuri - Dialogue list.

10 OSA 356. f. 1-4 1. c. The Script of the Film. Written by István Kemény and Pál Schiffer.

11 Submission on tasks related to the improvement of the situation of the Gypsy population. Meeting of the Political Bureau on 20 June 1961, HNA [Hungarian National Archives] M-KS-288. f. 5/1961/233. p. u. [p.u. - preservation unit]. Following this the Political Bureau had several debates on the issue: Report on the execution of the decree on various tasks regarding the improvement of the situation of the Gypsy population, Hungarian Socialist Workers' Party Political Bureau, 20 June 1961 (11 October 1962); Meeting of the Political Bureau, 5 March 1963; Plan on improving the housing situation of persons living in Gypsy settlements, 
the Kádár era ${ }^{[12]}$ sought to assimilate these communities and to place them under state supervision. ${ }^{[13]}$ Forced industrialization irrevocably transformed the traditional lifestyle of the majority of Gypsies, but it did little to change their position within society. "Socialist" industry generally viewed them as unskilled labor, and as such most of them filled the lowest positions in nationalized industries, while some were able to maintain their professions in areas where difficult conditions and low pay led to labor shortages. Large numbers worked in road construction, construction, and mining. Many were forced to leave their homes and migrate to industrial zones, move into workers' hostels, or commute long distances (Szuhay 1999, 43-44; Majtényi and Majtényi 2016). The story of Gyuri Cséplő presented this change - similar to official discourse of the era - as a path to upward mobility.

It was in the interest of companies to employ as many skilled workers as possible. Unskilled workers generally were employed for seasonal work and for larger projects. The workers themselves frequently changed jobs, and when they found another job, they terminated their employment "with arbitrary exit status." It was also typical that many people preserved their traditional jobs, mainly in the villages, and worked outside the state sector, and took a factory job only occasionally because of requirements to have registered employment. In fact, the socialist state did not offer everybody job opportunities everywhere. ${ }^{[14]}$ For example, the inhabitants of the settlement where Gyuri Cséplö lived were employed, in principle, by the local agricultural cooperative but, as is apparent from the film, they worked only seasonally. In the socialist state everybody had to justify some kind of employment before the authorities from time to time ("work avoiders" could be sentenced to prison). It was actually in the interest of the socialist power to create at least the semblance of full employment. While unemployment vanished from national statistics, real unemployment did not cease to exist during socialism.

It was not that unusual in the late 1970s that Gyuri Cséplö lived in a settlement of mud homes without running water or electricity. Although the elimination of the settlements did not bring any real results for a long time, the resettlement of Gypsy inhabitants actually started in 1965. ${ }^{[15]}$ The party-state wanted to provide a beautiful picture of the results of "socialist development" as soon as possible. According to the original concept, traditional Gypsy homes had to be destroyed where they were very easy to see: "First, those settlements should be eliminated which are situated near the national main roads and railways, furthermore in privileged areas, in the center of villages and towns or in other places which were important from the

Meeting of the Political Bureau on 12 November 1963; Recommendation on improving the situation of the Gypsy population and coordinating inter-ministerial committee work. Meeting of the Political Bureau, 15 October 1968; Report on the situation of the Gypsy population, Meeting of the Political Bureau 18 April 1979.

12 After the failure of the 1956 revolution in Hungary, János Kádár became the definitive political leader of the newly organized state party - the Hungarian Socialist Workers' Party - for over thirty years until his replacement in 1988.

13200,000 people are referred to in the party decree. The Central Statistical Office's 1963 income and stratification study saw statisticians estimate the Gypsy population at 222,000 persons based on the number of homes in the settlements.

14 HNA XIX-C-5 3. c. 27.229/1957.

15 According to Council reports; however, new Gypsy settlements were formed in the first year, from 1961 to 1962 (HNA XIX-I4-g 46. c. 66). 
point of view of tourism." ${ }^{[16]}$ In principle, Gypsy settlements were supposed to be eliminated (should have been eliminated) by 1975 within the "Fifteen-year Housing Development Plan." It was not implemented moreover, traditional mud-brick houses were built in villages even in the 1980s (Márfi 2008, 351) - and the majority of the Gypsy population continued to live in tough socioeconomic circumstances.

The first broad picture of the Gypsy population in Hungary was provided by a study led by István Kemény in 1971. The researchers estimated the number of Gypsies at 320,000 individuals, approximately three per cent of Hungary's citizens. They estimated that two-thirds of Gypsies still lived in Gypsy settlements, with more than two-thirds of them living in pisé or mud-brick homes. Forty-four per cent of their homes did not have electricity, while only eight per cent of homes had running water. Among Gypsies who were older than fourteen, the proportion of those who were illiterate was estimated at 39 per cent. It was easy to draw the conclusion that the research results signified a total failure of the party-state's Gypsy policies announced in 1961 through party decree, as well as that of social policy generally. ${ }^{[17]}$ In their study summarizing the results of the research, the sociologists provided a general picture of the disadvantaged social situation of Hungarian Gypsies, which was one and the same a critique of the partystate's social policy. Researchers obviously rejected the point of view of the socialist state although they also characterized Gypsies primarily through their disadvantageous social position, following on from the critical purpose of the research. In the summary report of his Gypsy research, István Kemény stated that the Gypsy population in itself does not constitute a separate social group $(1976,10)$. In his study, fearing the possibility of ethnic conflict stoked by his analysis of the underclass status of the majority of Gypsies, the sociologist summarized the consequences of relocations and ill-considered elimination of settlements: "The danger of new settlements established in such a way is that, due to their strong isolation, they run the risk of turning into a colourful ghetto" (Kemény 1976, 31).

According to the survey, the majority of the Gypsy population lived in poverty, and the phenomenon of poverty had been ethnicized in Hungary. However, studies carried out in that era, based on sociological and income statistics, estimated the proportion of the poor among the entire population at about ten per cent, and only one third of this group could be Gypsies. It is important to emphasize that due to the ideology of the system it was nearly impossible to discuss poverty in public in these decades. Hungary's first poverty study under socialism, launched in $1969,{ }^{[18]}$ was essentially an extension of a Central Statistical Office (Központi Statisztikai Hivatal - KSH) income distribution study from 1968. In 1970, István Kemény held an infamous lecture on contemporary poverty for an elite group of researchers at the Hungarian Academy of Sciences. Afterward he was removed temporarily from the Institute of Sociology: later, in 1972, the closing paper of the study was classified and locked in the KSH president's

16 Appendix to the intervention plan on the execution of Governmental Decree 2014/1964 on the dismantling of residential areas that do not meet adequate social conditions. Construction Ministry. Decree 17/1964. Ministry of Architecture.

17 For a summary of the research results: Kemény 1976. A report written in 1974 on the situation of the Gypsy population used data from the 1971 study and shed light on the gaps in executing Political Bureau decrees (HNA M-KS-288. f. 41/1974/226. p. u).

18 The project was launched with the euphemistic title: "A Study of the Life Circumstances of the Low-income Population." 
safe. ${ }^{[19]}$ In the socialist period the phenomenon of persistent poverty was taboo, and poverty only could be written or spoken about in the context of historical events or exceptionally as characteristic of the Gypsy population. ${ }^{[20]}$

Nevertheless, when the state dealt with the real situation of the poor, it mostly disguised its actions under its main Gypsy policy, primarily "the termination of settlements." ${ }^{[21]}$ The authorities uniformly presented the social problems of those living in slums, and social issues in general, as the Gypsy issue. Although representatives of the communist party, ministries, and local councils were quite aware that not only Gypsies lived under poor social conditions in Hungary, state intervention plans - thanks to the above - were exclusively under the banner of eradicating "Gypsy slums." Under the auspices of solving the "Gypsy problem" or eradicating "Gypsy slums" the authorities also executed several other social policy interventions that were deemed necessary (Valuch 2010; Majtényi 2018).

\section{The Process of Filmmaking ${ }^{[2]}$}

Poverty's social historical background in Hungary can explain to a degree why Gypsies became metaphoric characters in Hungarian documentaries and other representations of society during the socialist era. The metaphoric representation of Gypsies showed them - not independently from contemporary social, political, and cultural practices - as internal outsiders bound by marginalization, even during socialism. One may say that Gypsies - more exactly, the people regarded as Gypsies - were treated by the Hungarian state as if they were not part of Hungarian society. ${ }^{[23]}$ Any public critique related to social transformation only could be formulated in relation to the situation of Gypsies, including issues of social inequality and exclusion.

19 In 1973 István Kemény eventually was fired from the Hungarian Academy of Sciences' Institute of Sociology. Despite this, he continued to work on sociological research until 1976. In 1977 he emigrated to Paris, but the critical effect of his groundbreaking work continued to be felt. In Paris he teamed up with Péter Kende to launch Magyar Füzetek [Hungarian booklets] with the aim of bringing out pieces that could not be published in Hungary, through which he published a "manuscript" of his studies on poverty. In his writings and his notes read on Radio Free Europe he followed and criticized developments in Hungary. See Csizmadia 1991; F. Havas 2008 .

20 When regime-critical sociology and sociography began to deal with the topic once again, it became one of the forms of critiquing the regime's social policy, and as such was mostly excluded from official discourse (Majtényi 2014).

21 In 1970, for example, the affected state authorities prepared a study on "slums that did not meet social conditions," i.e., the results of the slum eradication projects. Officials concluded that the entirety of slums could not be eradicated within a reasonable time frame. According to this study, there were 755 Gypsy and 435 "mixed" slums in the country at the time. Characteristically, the authorities deemed cave dwellings and Budapest tenement houses "slums" to the same degree as shantytowns at the edge of villages. According to plan, 43 slums were to be eradicated under the fourth five-year plan, 536 under the fifth, 288 under the sixth, and the remaining 323 after 1986 (HNA XXVI-D-1-c 16. c).

22 On the metaphoric filmic usage of Gypsy/Romani characters, see Iordanova 2008; Rucker-Chang 2018.

23 Anikó Imre analyzes the issue of Gypsy/Romani representation in a global context. As Imre points out, the critical theories of 'whiteness' emphasize that the racist concept of "supremacy" was global, and as a hidden ideology it has determinated the East and Central European social history and representation of Gypsies as a racialized group (Imre 2005). 
After the Gypsy study carried out by István Kemény in 1971 examined and presented the Gypsy issue, it became the benchmark on poverty in Hungary. Photographs, sociographies, and documentaries about the lives of Gypsies depicted the failures of socialism and poverty during the socialist period. It is important to emphasize that Pál Schiffer also participated in the sociological research of 1971, and that sociologist István Kemény was a co-author of the script for Cséplő Gyuri. ${ }^{[24]}$

Two films by Pál Schiffer explored the possibility and the impossibility of breaking free from a Gypsy slum personified through two life stories: Cséplö Gyuri is about the former, whereas A pártfogolt (On probation - 1983) presents the latter (Tóth 2008). These films, which portrayed Gypsies and the lives of Gypsy individuals, did more than depict a topic: they became tools to criticize the system of actual existing socialism. They suggested that poverty continued to exist in socialism, and the director was looking to exhibit pathways out of it. The film Cséplö Gyuri primarily sought to show the possibility of emerging from poverty. In the "literary script" the scriptwriters formulated this goal as follows, referring to the sociological fact that not only Gypsies lived in poverty in Hungary:

We want to make an impact with our films: by means of our tools we want to contribute to Gypsies finding their place in Hungarian society. This is one of the reasons why we want to show that the Gypsy issue is actually a Hungarian issue, it is primarily not a racial or ethnic, but a social problem. ${ }^{[25]}$

The story of how Cséplö Gyuri was made is documented in the notes taken by Pál Schiffer, which are preserved in the OSA Archives: the first plan was made in 1974. It was, however, only possible to shoot the film two years later in 1976. One of the reasons for this was the above-mentioned sociological works of István Kemény, the co-author, who had sparked the anger of party leadership. It also can be assumed that it was not only the slander of the sociologist co-operating as a co-author and story-editor that had an unfavorable impact on the fate of the film. Both the topic and the method of elaboration were controversial for decision-makers. In fact, poverty was depicted in the film in a realistic way, which in principle could not exist in socialism. Furthermore, there were real debates about the funding, i.e., whether it should be shot as a documentary or a feature film. This was a crucial issue from the aspect of filmmaking as the latter "genre" would have provided a much larger budget. ${ }^{[26]}$

The director imagined that the film would have fictitious, arranged scenes. The film was shot according to a script written carefully in advance, so most scenes were arranged except on one or two occasions. However, some of the elements of the original concept were omitted by the filmmakers, for example, Gyuri's love for an intellectual girl named Erzsi, leader of the KISZ (Communist Youth Organization)

24 As Pál Schiffer said in an interview: "At the end of 1971 and in 1972 I was involved as an occasional driver, a boom operator, and a cassette recorder operator in the sociological study guided by the Council of Ministers, and carried out by the Sociological Institute to assess the situation of the Hungarian Gypsy population."

25 OSA 356. f. 1-4 1. c. Literary Script of the Film. Written by István Kemény and Pál Schiffer.

26 Finally, after two years, Balázs Béla Studio was commissioned to shoot the film, i.e., a documentary film was to be made. At that time Gyuri Cséplő, hoping for a better life, had already been waiting to get a job offer in Budapest for two years (Pócsik 2013). 
club (which might have seemed sociologically unrealistic). ${ }^{[27]}$ Instead, Gyuri Cséplö fell in love with a Gypsy girl who also was working in the capital. ${ }^{[28]}$

After the film was finished, the creators were advised to omit some shorter details at various public screenings. The film was first shown on 8 July 1977 before representatives of MOKÉP (Moving Picture Company) and the Main Directorate of Films, state organs that controlled the ideology of Hungarian filmmaking. They suggested cutting the 125-minute movie and primarily criticized the scenes in the brick factory, which presented life in a workers' settlement in Budapest. The idea of displaying the "common yard" of the brick factory, as Schiffer later recalled, came from "an existing sociological study and months of pre-studies that provided the basis for preparing this scene." His co-author István Kemény had already published research about the brick factory in Csillaghegy, and the scenes there emphasized that all low-paid workers struggled with poverty and isolation (Kemény 1990). During a later talk, Pál Schiffer explained the scene's significance: "Fundamentally, there is no difference between Hungarian proletarians living in the common courtyard of a brick factory and Gypsy agricultural proletarians living in a Gypsy settlement."[29]

It is worth noting that later this scene also aroused the interest of audiences at the film screenings. One viewer asked Pál Schiffer: "Would you please tell me if the brick factory really exists in Budapest?" With the thoroughness of a social scientist, he gave the following answer (representing that poverty is actually not a "Gypsy issue" in Hungary):

We have to acknowledge it [...] and we traditionally might call it a "lumpen [proletariat]" problem or we can translate the American term "stratum under society", an expression that I don't find very nice, while in Hungary we prefer to use the term "a poor worker, the stratum of unskilled workers," which is more or less correct, although it is actually incorrect, but according to existing statistical sociological data, about ten per cent of the population belongs to this stratum [...]. Within that, maybe one third, or even less, about 3.6 per cent to 3.8 per cent of the Gypsy population. So we can assume that three per cent of this 10 per cent are Gypsies. ${ }^{[30]}$

The Main Film Directorate finally made the decision that the scene in the common yard, especially its second half, should be shortened. In this part, a working woman referred to as a "woman wearing a green pullover" complained passionately about her living conditions in a debate. Furthermore, it was suggested

27 OSA 356. f. 1-4 2. c. Literary Script of the Film. II. 53.

28 We do not know what Gyuri Cséplös wife, who watched the film during one of film debates in Zala, thought about this fictional scene in Németfalu. In fact, there is no information about it in the sources.

29 OSA 356. f. 1-4 1. c. “Cséplő Gyuri debate," Esztergom (6 April 1978).

30 OSA 356. f. 1-4 1. c. During the production of the film, the director also conducted thorough sociological research projects with the help of István Kemény. 
by the officials of the Main Directorate of Films that the introduction also should be cut by the authors. Its pictures also presented poverty, i.e., the lives of Gypsies living in settlements. ${ }^{[31]}$

\section{The Aftermath}

However, some difficulties remained to be resolved, and the "classification" of the film was also questionable. After the "standard copies" had been made, it became apparent that MOKÉP (The Motion Picture Distributing and Sales Company) still treated the film as a documentary. They wanted to bring it out in marketing category five (i.e., with the lowest number of copies and a "propaganda frame"). By stressing the importance of the topic, the director, however, managed to convince the authorities that the film should be shown more widely. Finally, Cséplő Gyuri was first shown as a feature film at the Tenth Pécs Feature Film Festival in February 1978. It was played at cinemas from May and received a decent critical response and considerable attention. The aim of the film was also to reduce prejudice against Gypsies. When reading the descriptions of the film debates, it seems that Gyuri Cséplös appealing personality and his fate in the film aroused solidarity and empathy among some viewers.

Here is Gyuri Cséplö, who's not only Gyuri Cséplő who we can see here but also the role that he played in this film. I wonder whether those of you who never have met this young man got to like him after watching the film? (a man) - What's more, you might even feel sorry for him. ${ }^{[32]}$

According to a summary of the debates, the public became more aware about the "Gypsy issue" than ever before. The two main points made at these talks were Gypsy employment and benefits. Many of the participants mentioned their own prejudices. For example, several audience members cited rumors that Gypsies had removed and burnt the parquet in new homes they had received from the state. Furthermore, a majority of speakers thought that Gypsies should solve their own problems (Szekfü 2008, 198). Many urban viewers were astonished by the condition of the rural Gypsy settlements. Others were shocked once when they realized that the film was not just about Gypsies but also about "Hungarians" who often lived the same way as "they" did (Szekfü 2008, 204). It is typical that one speaker thought that, without help, he had less of a chance to break free of poverty than Gyuri Cséplö. He presented his own story like this:

I was in just such a situation. Once I finished eight years of primary school, I went and worked at the state farm. Last autumn it was announced that we had to go school to learn how to drive a tractor. Three of us who finished primary school were sent to a center. There

\footnotetext{
31 Moreover, István B. Szabó even asked the authors to examine the scene in the brick factory in which Gyuri Cséplő uttered "three obscene expressions." Thus finally the film was five minutes and two swear words shorter (the authors, however, kept one of them for the sake of the atmosphere).
} 
we were told that we were Gypsies and we weren't allowed to go to school. This is what happened, they hindered our further development, and that was it. ${ }^{[33]}$

Several people remarked during the film debate that perhaps the hero had made a bad decision coming to Budapest. For example, a tenant at a workers' hostel on Kerepes Street said the following: "I'm also a country man, and he shouldn't have come to Pest, at least this is what I think." ${ }^{[34]}$

Pál Schiffer answered at great length, not hiding his own doubts, either.

Well, are the people who live at the workers' hostel the same as the community, the relatives, friends, the children, as those who you grew up with or do you find similar people there? Well, you can judge it better than me because in the case of Gyuri the problem was that he really missed the people who he grew up with and those who didn't just mean company for him .... ${ }^{[35]}$

After the screenings viewers often were interested in finding out whether it was possible to break free from poverty, and concretely what later happened to Gyuri Cséplö. At that time the filmmakers regretted to inform them that the main character of the film "was ill at present." One of the filmmakers (probably Pál Schiffer, although the names of this discussion were not given in the transcript) said the following about him in a transcript:

Well, this is a strange story. Unfortunately, it isn't completely typical. And, unfortunately, it's completely typical. This is why it's very sad as the film ends with an optimistic tone or sadness [...] and he goes again to Budapest. Let's say that this is the meaning of this last picture. It suited the situation in which he was in when the film ended. Unfortunately, since then his health has deteriorated. ${ }^{[36]}$

Then he added: "Three Gypsy families plan to move from the settlement into the village," by which he indicated that something had happened as a result of the film, if not in the life of the individual, then at least in the life of the community.

A debate also was held at the construction company where Gyuri Cséplő worked in the film. József Rézmüves (Jóska), who also acted in the film and worked with him on the building site, also turned up at this talk. The workers watching the film had a row over wages (the injustice of wage differences), as they were affected directly by the film, and many of them also watched the shooting of the film. ${ }^{[37]}$

33 OSA 356. f. 1-4 1. c. “Cséplő Gyuri debate," Budapest, workers' hostel in Kerepesi street (26 April 1978).

34 OSA 356. f. 1-4 1. c. “Cséplő Gyuri debate,” Budapest, workers’ hostel in Kerepesi street (26 April 1978).

35 OSA 356. f. 1-4 1. c. “Cséplő Gyuri debate,” Budapest, workers’ hostel in Kerepesi street (26 April 1978).

36 OSA 356. f. 1-4 1. c. “Cséplő Gyuri debate,” Bakonyoszlop (29 April 1978).

37 OSA 356. f. 1-4 1. c. “Cséplő Gyuri debate,” Budapest, No. I. Company of Building Industry (13 April 1978). 
It was also clear from this conversation that there were many conflicts among members of various working groups. However, such a personal argument rarely happened since the topic of their conversation was usually the life story of the main character. When we read the transcripts of the debates following the screenings, it is striking that the participants (who discussed the film with the director or one of his colleagues) were mostly interested in the fate of Gyuri Cséplö. What they least wanted to believe and accept was the story as it was told, i.e., that he did not regret his decision as a young man to leave the settlement or that he really did succeed in being integrated into the world of the workers' hostel in Budapest. One of them put it like this: “... while my colleague and I were leaving, we were burning with curiosity to ask whether his relations and circumstances had really changed since the screening of the film, whether he was working, whether he was in full employment, and so on."[38]

\section{The Tragic Death of Gyuri Cséplö}

In fact, Gyuri Cséplő worked at the brick factory in Budapest for one more month, then he was unable to work and was given a disability allowance because of heart disease. He started to build a house in Németfalu after taking out a loan, which he received with the help of Pál Schiffer, and he started farming. However, in September 1978, shortly after the film was shown, he died at the age of 25 . From the messages exchanged between Gyuri Cséplö and the director (sometimes other people wrote and sent a message instead of "Gyuri," especially when he was unwell), it turns out that he regularly asked the director for financial support. The brief news coming from Gyuri Cséplö in telegrams can even be read as a drama of linguistic minimalism, ${ }^{[39]}$ and they reveal his almost hopeless financial situation and his illness which was rapidly undermining his strength.

Pál Schiffer was shocked and saddened by the early death of his acquaintance and protégé, Gyuri Cséplö. He tried to find out as many details as possible about the cause of his death. It became apparent that, in addition to the unhealthy circumstances of his childhood and youth, Gyuri's condition became fatal because he received neither proper nor timely medical treatment from the local hospital and health service. The director said the following in an interview:

We sent him to a heart clinic for a medical exam before the film, and they concluded that he was in a compensated state. One year later, when he had connections and a reputation as an actor, he was sent to OTKI (Health Education and Training Institute), and there his case was evaluated as manslaughter, which every heart surgeon acknowledges. They were forced to kill people, as forty out of one hundred patients will be operated in time, while for sixty of them it was too late. Such are the conditions. Obviously, when his illness was diagnosed for the first time, his doctor in the county hospital thought consciously or not that it was no use operating on him because he wouldn't do a white collar job even then,

38 OSA 356. f. 1-4 1. c. “Cséplő Gyuri debate.” Zalakomár (1978).

39 OSA 356. f. 1-4 1. c. Letters of Gyuri Cséplő; OSA 356-1-4 2. c. Letters from Németfalu and from the Cséplő-family (1977-1983). 
and he wouldn't be able to do a blue collar job even after the operation, so he should work as long as he could. ${ }^{[40]}$

Ultimately, the doubt and guilt felt by the director were generated by the question of whether or not the strenuous physical labour that Gyuri Cséplö took on for the film had contributed to his death, and in what direction his role in the film influenced his end. Pál Schiffer's notes suggest that Gyuri Cséplö’s death made him uncertain about the story and the message of the film. The death of the protagonist confronted him with many questions which he believed that he already had answered. ${ }^{[41]}$

The film also forced him to change his view on the possibility of social mobility. János Kitka, the protagonist of Schiffer's next film A pártfogolt (On probation - 1981), is the son of one of the commuting workers in an earlier film titled Fekete vonat (Black train). The genre of the film was again situational documentary, and its main character was an ordinary person who plays himself. János Kitka has been released from a juvenile detention center, and like Gyuri Cséplő, he also toys with the idea of finding a job in Budapest, but he is less successful. All his attempts fail, and in the closing scene, we see him at home again, in the yard of his farmstead. The new documentary transmitted very different messages about socialist society to the public than Csépló Gyuri. The film seems to argue that the socialist system did not really offer any real chance for social mobility to Gypsies, and generally to the those who had to live in poverty in socialist Hungary.

\section{Conclusion}

On the whole, the real core of the bargaining around the production of Cséplö Gyuri did not merely have to do with the aspects of the distribution or its peculiar genre. In fact, it was the documentary's depiction of poverty that triggered real debate, i.e., how was it possible to show such pictures of poverty like the shots recorded at the workers' homes at the brick factory. The topic itself - the "rise" of Gypsies (even if it pointed out its difficulties) - received a green light. Today, this is perhaps the most problematic part of the film. ${ }^{[42]}$ It is questionable whether the journey that the film's protagonist undertook was a real opportunity for the poor, including Gypsies, and if it was, what was its meaning at that time (whether it really meant an upward social mobility).

With the film Cséplö Gyuri, one of the authors' main goals was to show another world outside socialist Hungary, the existence of poverty, and to provide a critique of the system. In that era almost all documentary filmmakers and sociologists criticized how social goals set by the socialist state were realized. However, they hardly reflected on the reality of the image of the future, which the party-state outlined and according to which the (only possible) path to social mobility meant taking on industrial

40 OSA 356. f. 1-4 2. c. How Did Gyuri Cséplő Die? 1979.

41 OSA 356. f. 1-4 2. c. How Did Gyuri Cséplő Die? 1979.

42 OSA 356. f. 1-4 1. c. Schiffer Pál Notes on the making of his movie. 
work, breaking away from traditional lives, i.e., one's own community, and moving to the city. Gyuri Cséplö's real fate, his life outside the film, makes us feel unsure (and it made Pál Schiffer feel very unsure) about whether these steps were worth taking in order to break free from poverty and Gypsy settlements. His death symbolized a socialist regime that did not provide equal opportunities to all its citizens. An even more crucial question, especially to intellectuals critical of the system, was where the road of socialism was leading, how the future could be shaped, and whether it was possible to create a more just society. It is questionable how much people were concerned about the realization of socialism in their everyday lives or how the existence of the system or socialist modernization influenced the lives of minority communities. As debate participants remarked in Zalaapát: "The life of one person is as much as they live it, as much as they can live it." ${ }^{[43]}$ Thus, all that lies beyond that view does not really exist for them. The value system related and was made to relate to the operation of state institutions and was presumably not known or acceptable for everybody in that era.

According to theories about "multiple modernities," in the process of history certain phenomena did not simply result from one another, but they could even exist side by side (in their own space and time). Thus they cannot be understood in their own multiplicity if we see and analyze them as the parts of the same process in the spirit of the linear conception of time typical of modernity. In general, it is also questionable whether the feeling of progress and development ever manifested itself in the everyday life and experiences of ordinary people, whether the socialist transformation had a similar impact on the various groups of society, such as upper and lower classes or majority and minority communities.

Gyuri Cséplö's story is an outstanding example of how great national state narratives may not necessarily be applied to describe or fit the history of Gypsy/Romani communities - and minority communities or lower social classes in general - forced into society's periphery. To this day, there are ongoing debates among historians and intellectuals about the real relationship between true socialism and actually "existing"/"existed socialism." However, there also can be such a point of view, and perhaps from this point of view we can perceive most of the experiences of everyday people from that era - and perhaps Gyuri Cséplő's is like that - according to which socialism simply did not exist; there was no such a thing.

\section{References}

Apor, Péter. 2009. “Cigányok tere: kísérlet a kommunista cigánypolitika közép-kelet-európai összehasonlító értelmezésére, 1945-1961” (The space of Gypsies: An interpretation of the birth of Communist Roma policy in East-European comparison, 1945-1961). Aetas 2: 69-86.

Bakó, Ferenc. 1954. “A tiszaigari cigányok fémművessége (Gypsy metal-work in Tiszaigar] Néprajzi Értesítő 36: 239-258.

Bancroft, Angus. 2005. Roma and Gypsy-Travellers in Europe: Modernity, Race, Space and Exclusion. Aldershot: Ashgate. 
Csizmadia, Ervin. 1991. "Megfelezett élet. Csizmadia Ervin beszélgetése Kemény István szociológussal” (A split life. An interview with sociologist István Kemény by Ervin Csizmadia). In Közelröl s távolból (Close view from a distance), edited by István Kemény, 179-189. Budapest: Gondolat.

David-Fox, Michael. 2006. "Multiple Modernities vs. Neo-Traditionalism: On Recent Debates in Russian and Soviet History”. Jahrbücher für Geschichte Osteuropas 54: 535-555.

DeCuir, Greg. et al. 2011. Yugoslav Black Wave: Polemical Cinema from 1963-1973 in the Socialist Federal Republic of Yugoslavia. Belgrade: Film Center Serbia.

Eisenstadt, Shmuel N. 2003. Comparative Civilizations and Multiple Modernities. Two volumes. Boston: Brill.

F. Havas, Gábor. 2008. “Kemény István, 1925-2008.” Beszélő (13) 5: 62-66.

Giddens, Anthony. 1990. The Consequences of Modernity. Berkeley: Stanford University Press.

Gunda, Béla. 1956. Néprajzi gyüjtőúton (On an ethnographic research trip). Debrecen: Alföldi Magvető.

György, Eszter. 2019. "An attempt to create minority heritage: The history of the Rom Som club (Rom Som cigányklub) (1972-1980).” Romani Studies 29 (2): 205 - 232. DOI: https://doi.org/10.3828/rs.2019.9

Imre, Anikó. 2005. "Whiteness in Post-Socialist Eastern Europe: The Time of the Gypsies, The End of Race" In Postcolonial Whiteness: A Critical Reader on Race and Empire, edited by Alfred J. López, 79-102. Albany: State University of New York Press.

Iordanova, Dina. 2008. “Mimicry and Plagiarism: Reconciling Actual and Metaphoric Gypsies.” Third Text 22 (3): 305-310.

Kemény, Imre. 1976. A magyarországi cigányok helyzete (The status of Gypsies of Hungary). In: Beszámoló a magyarországi cigányok helyzetével foglalkozó 1971-ben végzett kutatásról (Report on research carried out in 1971 on the situation of Gypsies in Hungary), edited by Imre Kemény, 7-67. Budapest: MTA Szociológiai Kutató Intézet.

1990 [1973]. A Csillaghegyi Téglagyár munkásai (Workers of the brick factory of Csillaghegy). In Velük nevelkedett a gép: Magyar munkások a hetvenes évek elején. (Szociológiai tanulmányok), edited by Imre Kemény, 21-28. Budapest: VITA.

Kovács, Éva. 2009. “Fekete testek, fehér testek” (Black bodies, white bodies). Beszélő 14. http://beszelo.c3.hu/cikkek/ fekete-testek-feher-testek

Ladvenicza, Ilona M. 1955. “A csobánkai cigányok szegkovácsolása” (The nail-smith Gypsies in Csobánka). Néprajzi Értesítö 37: 227-241.

Lindenberger, Thomas. 2003. "Das Fremde im Eigenen de Staatsocialismus. Klassendiskurs und Exklusion am Beispiel der Konstruktion des 'asozialen Verhaltens.” In Fremde und Fremd-Sein in der DDR. Zu den historischen Ursachen der Fremdenfeindlichkeit in Ostdeutschland, edited by Jan C. Behrends, Thomas Lindenberger, and Patrice G. Poutrus, 179-191. Berlin, Metropol Verlag.

Lucassen, Leo. 2008. "Between Hobbes and Locke. Gypsies and the Limits of the Modernization Paradigm.” Social History 33 (4): 423-441.

Majtényi, György. 2014. Texts, Structures and Experiences: The Society of State Socialist Hungary in Historical Perspective. SOCIO.HU (Spec). doi: 10.18030/socio.hu.2014en.96

. 2018. Egy forint krumplis lángos. A Kádár-kor társadalmi (One forint potato fry bread. The society of the Kádár era). Budapest: Libri. 
Majtényi, Balázs, and György Majtényi. 2016. A Contemporary History of Exclusion: The Roma Issue in Hungary from 1945 to 2015. Budapest: CEU Press.

Márfi, Attila. 2008. "Cigánysors, cigánykérdés; a vályogtelepek felszámolása Baranyában a tanácskorszak idején” (Gypsy fate, Gypsy issue). In Távolodás és közelitések. Rendszerváltás és Kádár-korszak (The regime change and the Kádár-era), edited by Majtényi György, and Szabó Csaba, 339-353. Budapest: Állambiztonsági Szolgálatok Történeti Levéltára -Kossuth.

Pócsik, Andrea. 2013. "Én, Cséplő György. Schiffer Pál dokumentumfilmjei és a Cséplő Gyuri” (Me, György Cséplő: Pál Schiffer's Documentaries and Gyuri Cséplö). Apertúra: filmelméleti és filmtörténeti online szakfolyóirat. Apertura.hu

Rucker-Chang, Sunnie. 2018. "African-American and Romani Filmic Representation and the 'Posts' of Post-Civil Rights and Post-EU Expansion.” Critical Romani Studies 1 (1): 132-148. https://doi.org/10.29098/crs.v1i1.8

Szekfü, András. 1980. "Közvélemény, cigánykérdés és egy film ankétjai" (Public opinion, the Gypsy issue, and debates of a film). Jel-kép 1: 142-149.

—. 2008. A cápa utolsó tangója - Médiaszociológiai tanulmányok a félkemény diktatúrában (Mediasociological studies from the half-hard dictatorship). Budapest: Gondolat-Infonia.

Szuhay, Péter. 1999. "Foglalkozási és megélhetési stratégiák a magyarországi cigányok körében” (Strategies for employment and living among Gypsies in Hungary). In A cigányok Magyarországon (The Roma in Hungary), edited by Ferenc Glatz, 43-44. Budapest: Magyar Tudományos Akadémia.

Tóth, Eszter Zs. 2008. “Fekete vonat, Cséplő Gyuri, A pártfogolt - ingázók dokumentumfilmeken” (Black train, Gyuri Cséplő, On probation - Commuters in documentaries). Eszmélet 77: 50-75.

Valuch, Tibor. 2010. "Szegény ember vízzel főz." Adalékok a magyarországi szegénység történetéhez a XX. század második felében ("The poor cook with water." Contributions to the history of poverty in Hungary in the second half of the twentieth century). In Megtalálható-e a múlt? Tanulmányok Gyáni Gábor 60. születésnapjára, edited by Tibor Valuch, Zsombor Bódy, and Sándor Horváth, 269-281. Budapest: Argumentum.

Wolff, Larry. 1997. Inventing Eastern Europe. The Map of Civilization and the Mind of the Enlightenment. Berkeley: Stanford University Press. 